\title{
FOREIGN TRADE CONCENTRATION: THE CASE OF DENIZLI PROVINCE IN TURKEY
}

DOI: 10.17261/Pressacademia.2019.1170

JEFA- V.6-ISS.4-2019(6)-p.236-247

\section{Aysun Karadayi}

Pamukkale University, PhD Program in Management, Aydin, Turkey. aysun.karadayi@gmail.com, ORCID: 0000-0002-0485-5773

Date Received: October 21, 2019

Date Accepted: December 23, 2019

To cite this document

Karadayı, A., (2019). Foreign Trade Concentration: The Case of Denizli Province in Turkey. Journal of Economics, Finance and Accounting (JEFA), V.6(4), p.236-247.

Permemant link to this document: http://doi.org/10.17261/Pressacademia.2019.1170

Copyright: Published by PressAcademia and limited licenced re-use rights only.

\section{ABSTRACT}

Purpose- In this study, for the period 2012-2016, foreign trade data on Denizli, South Aegean (TR32) Region and Turkey basis were examined and provincial, regional and country-level evaluations were carried out by the comparison method.

Methodology- The export and import concentration ratios for Denizli and South Aegean Region were calculated and subsequently market and sectoral concentration conditions on the provincial and regional level were evaluated. In addition, export and import concentration coefficients for Denizli were calculated and the sectors that are prominent in provincial foreign trade were determined.

Findings- The results showed that even though fluctuations in the period examined, Denizli and South Aegean Region have a certain foreign trade trend and that the sectoral concentration in the foreign trade of Denizli is higher than the market concentration of it. Concentration coefficients calculated for Denizli province demonstrated that Textile Products, N.E.C. Electrical Machines and Devices, Other Non-Metallic Mineral Products, Metal Goods Industry, Quarrying and Other Mining, Clothing and Base Metal Industry are the most prominent sectors in provincial exports while Base Metal Industry, Textile Products, Paper and Paper Products, Wood and Cork Products, Agriculture and Livestock are the prominent sectors in provincial imports.

Conclusion- Sectoral concentration may not be considered as a negative situation if it is derived from a real specialization in the concentrated sectors and thus high value-added production. The production and export strategy of the province can be established both on the basis of increasing the value-added in certain sectors and also on increasing the sector and product diversity in production and export.

Keywords: Denizli, concentration ratio, concentration coefficient, market concentration, sectoral concentration.

JEL Codes: F10, F14, O24

\section{DIŞ TICARETTE YOĞUNLAŞMA: TÜRKIYY'DEN DENIZLi iLi ÖRNEĞi}

\section{ÖZET}

Amaç- Bu çalışmada 2012-2016 dönemi için Denizli, Güney Ege (TR32) Bölgesi ve Türkiye bazında dış ticaret verileri incelenmiştir ve il, bölge ve ülke düzeyinde karşılaştırma yöntemi ile değerlendirmeler yapılmıştır.

Yöntem- Denizli ve Güney Ege Bölgesi için ihracat ve ithalat yoğunlaşma oranları hesaplanarak pazar ve sektörel yoğunlaşma durumları değerlendirilmiştir. Ayrıca Denizli için ihracat ve ithalat yoğunlaşma katsayıları hesaplanarak il dış ticaretinde öne çıkan sektörler tespit edilmiştir.

Bulgular- Ulaşılan sonuçlar incelenen dönemde dalgalanmalar olsa da Denizli'nin ve Güney Ege Bölgesi'nin belli bir dış ticaret eğilimine sahip olduğunu ve dış ticarette sektörel yoğunlaşmanın pazar yoğunlaşmasından daha yüksek olduğunu göstermiştir. Denizli ili için hesaplanan yoğunlaşma katsayıları, il ihracatında öne çıkan sektörlerin Tekstil Ürünleri, B.Y.S. Elektrikli Makine ve Cihazlar, Metalik Olmayan Diğer Mineral Ürünler, Metal Eşya Sanayi, Taşocakçılığı ve Diğer Madencilik, Giyim Eşyası ve Ana Metal Sanayi olduğunu; il ithalatında öne çıkan sektörlerin ise Ana Metal Sanayi, Tekstil Ürünleri, Kâğıt ve Kâğıt Ürünleri, Ağaç ve Mantar Ürünleri, Tarım ve Hayvancılık olduğunu göstermiştir. Sonuç- Sektörel yoğunlaşma eğer yoğunlaşılan sektörlerde gerçek bir uzmanlaşma olmasından ve bu sayede yüksek katma değerli üretim yapılmasından kaynaklanıyorsa olumsuz bir durum olarak değerlendirilmeyebilir. İlin üretim ve ihracat stratejisi belli sektörlerde katma değer artışı sağlanması üzerine kurulabileceği gibi üretim ve ihracatta sektör ve ürün çeşitliliğinin artırılması üzerine de kurulabilir.

Anahtar Kelimeler: Denizli, yoğunlaşma oranı, yoğunlaşma katsayısı, pazar yoğunlaşması, sektörel yoğunlaşma JEL Kodları: F10, F14, O24

\section{GiRiş}


1945 yılından sonra literatürde yerini alan "Kalkınma" kavramına ilişkin paradigmalar günümüze kadar önemli değişimler geçirmiştir. 1970'lerin ikinci yarısına kadar hâkim olan yaklaşımda "Kalkınma" bir modernleşme projesi olarak tanımlanmıştır ve temel amacı az gelişmiş ülkelerin (bölgelerin), batılı (gelişmiş) ülkelerin toplumsal ve ekonomik refah düzeyine erişebilmesi olmuştur. Bu dönemde kalkınmanın itici gücü olarak "sanayileşmeye dayalı ekonomik büyüme” görülmüştür. 1990'ı yıllardan itibaren hâkim olmaya başlayan kalkınma paradigması ise "sürdürülebilir insani kalkınma" odaklıdır ve bu anlayışa göre toplumların esas zenginliği insanlarıdır. Bu paradigma değişimi sonucunda "Kalkınma" kavramı; başlangıçtaki ekonomik boyutuna sosyal, ekolojik, politik, kültürel, yaşam kalitesi, sosyal uyum ve refah boyutları eklemlenerek genişletilmiştir (Akın, 2006).

Benzer şekilde, klasik anlamda temel amacı bölgelerarası gelişmişlik farklılıklarının en aza indirilmesi olan "Bölgesel Kalkınma" kavramı da zaman içinde değişikliğe uğramıştır. Bölgesel kalkınmanın günümüz amaçları arasında bölgelerin küresel rekabet güçlerinin artırılması, yerel ve bölgesel potansiyelin harekete geçirilmesi suretiyle ulusal büyüme ve kalkınmaya katkılarının azami seviyeye çıkarılması da yer almaktadır. Bu bakış açısının bir yansıması olarak ülkemizin Dokuzuncu Kalkınma Planının (2007-2013) "Bölgesel Gelişmenin Sağlanması" ekseni altında; bölgesel gelişme politikasının merkezi düzeyde etkinleştirilmesi, yerel dinamiklere ve içsel potansiyele dayalı gelişmenin sağlanması, yerel düzeyde kurumsal kapasitenin artırılması ve kırsal kesimde kalkınmanın sağlanması hedeflerine yer verilmiştir.

Küreselleşen dünyada dış ticaretin katkısı olmadan kalkınmanın sağlanamayacağı genel kabul görmüş bir görüştür. Ülkemiz açısından bakıldığında üretim ve ihracatımızın yüksek katma değerli ve teknoloji yoğun bir yapıya kavuşması için yapısal bir dönüşüm ihtiyacı bulunduğu görülmektedir. Cari işlemler açığı veren Türkiye ekonomisinde üretim kapasitesi ve ihracatı artıracak yatırımlara öncelik verilmesi gerektiği Onuncu Kalkınma Planında (2014-2018) yer verilen bir husus olmuştur. Plan döneminde reel olarak ortalama ihracat artışının ithalat artışından yüksek olması, ihracatın ithalata olan bağımlılığının azaltılması, ihracat içinde orta-yüksek ve yüksek teknolojili imalat sanayii ürünlerinin payının yükseltilmesi, hizmet ihracatının artırılması ve çeşitlendirilmesi hedeflenmiştir.

İhracat artışı kadar ihracat çeşitlendirmesi de önemli bir konudur. İhracat çeşitlendirmesi ülke ihracatının pek çok sektör (ürün) ve ülkeye (pazar) yayılması anlamına gelir ve bu sayede ülke dışsal risk, kriz ve şoklara karşı daha dayanıklı hale gelir. Bu doğrultuda Onuncu Kalkınma Planı döneminde, Türkiye'nin geleneksel ihracat pazarlarındaki payını düşürmeden, AB-dışı ülkelere mal ve hizmet ihracatını artırması hedeflenmiştir.

Ulusal ve bölgesel kaynakların etkin kullanılması zorunluluğu doğrultusunda Türkiye'de kaynakların daha çok refah üreten alanlara yönlendirilmesi ihtiyacı vardır. Bu yönde karar verici olanlar ve ilgili taraflara yol göstermesi açısından, bu çalışmada 2012-2016 dönemi için Denizli ilinin dış ticaret analizi yapılmıştır. Analizde Yoğunlaşma Oranı, Yoğunlaşma Katsayısı ve Karşılaştırma yöntemleri kullanılmıştır.

Denizli ilinin 2017 yılı nüfusu 1.018.735 kişidir, nüfus yoğunluğu bakımından Türkiye illeri arasında 26'ıncı sıradadır (TÜik, 2017) ve sosyoekonomik gelişmişlik endeksi sıralamasında 10'uncu sıradadır (Kalkınma Bakanlığı, 2013). 2014 yılında ilde; GSYH 24.056 milyon TL, kişi başına GSYH 24.772 TL veya 11.327 USD'dir (TÜiK, 2014).

Çalışma beş bölümden oluşmaktadır. Giriş bölümünden sonra ikinci bölümde Literatür Araştırması, üçüncü bölümde veri ve yöntem, dördüncü bölümde bulgu ve tartışmalar ve beşinci bölümde sonuç yer almaktadır.

\section{LITERATÜR ARAŞTIRMASI}

Yoğunlaşma Analizi bölgelerin ekonomik faaliyetler yönünden karşılaştırılması ve göreli olarak uzmanlaştığı sektörlerin tespitinde kullanılmaktadır. Firma, ürün, sektör, ülke (pazar) bazında yoğunlaşmaların ele alındığı çalışmalara odaklanarak yapılan literatür araştırmasında taranan çalışmalara bu bölümde değinilmektedir.

Wolff (2000) tarafından yapılan çalışmada; 1970-1997 yılları arasında 33 imalat malında 14 OECD ülkesi baz alınarak, söz konusu ülkelerin ihracat uzmanlaşma ve benzerlik dereceleri ölçülmüştür. Bununla birlikte, Kanada ve ABD'nin geleceğe yönelik uzmanlaşma dereceleri tahmin edilmiştir. Sonuçlar; Kanada'nın ulaştırma ekipmanları, özel karayolu taşıtları, motor araçları, demir ihtiva etmeyen metal ve ağaç ürünlerinde uzmanlaştığını ve ABD'nin uçak, profesyonel ürünler, petrol ve kömür ürünlerinde yüksek oranda nispi üstünlüğe sahip olduğunu ortaya koymuştur.

Kaya (2006) çalışmasında; 1991-2003 döneminde, imalat sanayi ihracatında, Türkiye'nin AB-15 ve AB-10 ile Bulgaristan, Romanya gibi aday ülkeler karşısında üstünlük sahibi olduğu endüstriler belirlenmeye çalışılmıştır. Çalışmada imalat sanayi ihracat verileri kullanılmıştır. Balassa Endeksi kullanılarak yapılan analiz sonucunda, 151 imalat sanayi alt ürün grubu içinde 53 endüstride AKÜ (Açıklanmış Karşılaştırmalı Üstünlük) 1 tespit edilmiştir. Türkiye'nin karşılaştırmalı üstün olduğu 53 maldan 1'i hammadde yoğun, 27 'si emek yoğun, 16'sı sermaye yoğun, 9'u zor taklit edilen araştırma yoğun mallar olarak tespit edilmiştir. 
Hamid (2008) çalışmasında; 1970-1993 dönemi için Malezya'da pazar ve ürün yoğunlaşması incelenmiş ve ticaret deseni ve istikrarsızlığın zaman içinde nasıl değiştiği analiz edilmiştir. İstikrarsızlık endeksi, ürün yoğunlaşması, pazar yoğunlaşması ve birincil ürün ihracatının payını içeren bir dizi açıklayıcı değişken ile regresyon analizine tabi tutulmuştur. Sonuçlar, ürün yoğunlaşmasının ihracat gelirlerinin dengesizliğini açıklayan önemli bir değişken olarak ortaya çıktığını göstermektedir. İstikrarsızlı̆ın olumsuz etkilerinden korunmak için Malezya'nın; verimliliği üretim maliyetinden yüksek tutma, endüstri tabanını genişleterek çeşitlendirme ve yeni ürünler için sürekli yeni pazarlar bulmak suretiyle rekabeti sürdürme konusunda sürekli bir çaba içinde olması gerektiği yönünde öneriler sunulmuştur.

Hesse (2008) çalışmasında; ihracat çeşitlendirmesinin kişi başına gelir büyümesi üzerindeki olumlu etkisine dair sağlam ampirik kanıtlar sağlandığı ileri sürülmektedir. İhracat çeşitlendirmesinin daha yüksek büyümeye yol açtığı ve gelişmekte olan ülkelerin çeşitlendirme ile ihracat istikrarsızlığının veya birincil ticaret ürünleri ticaret koşullarındaki olumsuz etkilerin üstesinden gelebilecekleri değerlendirilmiştir.

Akal (2009) çalışmasında; 1995 - 2005 döneminde Türkiye'nin Rusya ve Ukrayna ile dış ticaretinde meydana gelen ihracat, ithalat, avantajlı ve dezavantajlı fasıl yoğunlaşması ve değişimleri ortaya koyulmuştur. Araştırma sonucunda toplam 200 milyon nüfuslarıyla farklı gelir gruplarına sahip Rusya ve Ukrayna'nın piyasa ekonomisine geçişlerinin Türkiye'den olan mal talebi fasıllarında değişimlere yol açtığı tespit edilmiştir. Türkiye'nin Rusya ve Ukrayna'dan ithalatının Mineral Yakıtlar, Mineral Yağlar ve Ürünleri, Mumlar ile Demir ve Çelik fasıllarında yoğunlaştığı görülmüştür. Türkiye bu iki ülkeden doğal kaynak yoğunluklu mallar ithal ederken, ihraç edilen mallarda yoğunlaşmanın düşük teknoloji ile emek yoğun üretilen mallardan orta ve ileri teknoloji ile sermaye yoğun üretilen mallara ve bunların oluşturduğu fasıllara kaydığı görülmüştür. Bir diğer çalışmasında Akal (2008), 1980-2005 dönemi için Türkiye'nin Ortadoğu sınır ülkeleriyle (Irak, İran, Suriye) olan dış ticaretinde fasıl bazında ihracat ve ithalat yoğunlaşmalarını incelemiştir. Türkiye'nin bu ülkelere olan ihracatı tarımsal fasıllardan sanayi fasıllarına, emek yoğun fasıllardan sermaye ve teknoloji içeren fasıl yoğunlaşmasına kaymıştır.

Ayrancı (2009) çalışmasında; Türkiye'nin ekonomik açıdan küreselleşmesi konu edilmiştir. Ekonomik küreselleşmenin bir boyutu olan dış ticaret yoğunlaşması 1996-2004 dönemi için incelenmiş ve Herfındahl-Hirschman Endeksi kullanılarak analiz yapılmıştır. Araştırma sonuçları; Türkiye'nin dış ticaret yoğunlaşmasının azalma eğilimi gösterdiğini ve buna göre Türkiye'nin dış ticaret açısından küreselleşme eğilimi sergilediğini göstermiştir.

Arip, Yee, Karim (2010) çalışmasında; 1980-2007 dönemi için Malezya'da ihracat çeşitlemesi ve ekonomik büyüme arasındaki ilişki incelenmiştir. Koentegrasyon ve Granger nedensellik test sonuçları değişkenler arasında benzersiz bir eş-bütünleşme vektörünün varlığını göstermiştir. İhracat çeşitlendirmesinin Malezya'daki ekonomik büyüme üzerinde önemli rol oynadığı bulgusundan hareketle çok taraflı ve bölgesel ticaret serbestleşmesi etkisi altında gelecekte ekonomik büyümeyi sürdürebilmek için Malezya'nın ihracat mallarını çeşitlendirmesi ve dünyanın geri kalanıyla daha büyük sosyal ve ekonomik işbirliği geliştirmesi gerekliliği ortaya koyulmuştur.

Doğan ve Kaya (2011) çalışmasında; Türkiye'nin dış ticaretinde Gümrük Birliği sonrasında ülke ve fasıl bazlı değişimleri ortaya koymak amacıyla yoğunlaşma oranı (CR) ve Herfindahl Endeksi (H-I) yöntemleri kullanılarak yoğunlaşma analizi yapılmıştır. Analiz sonucunda; ülke bazında hem ithalatta hem ihracatta ilk dört sırada yer alan ülkeleri kapsayan $\mathrm{CR}_{4}$ oranında bir değişiklik olmadığı; ürün bazında ise ihracatta düşük teknoloji grubu mallardan orta üst teknoloji grubu mallara geçilirken, ithalatta orta üst teknoloji grubu malların ve sermaye girdisi fasılları payının azalmadığı saptanmıştır. Buna göre, Avrupa Birliği'ne yapılan ihracatta yapısal bir değişim gözlenirken, ithalatta Avrupa Birliği'ne bağımlılı̆ıın azalması yönünde yapısal bir değişim sağlanamadığı değerlendirmesi yapılmıştır.

Gündem ve Acar (2011) çalışmasında; Türkiye imalat sanayindeki bölgesel uzmanlaşmaları saptamak amacıyla istihdam verileri ile firma sayısı verileri kullanıımış ve piyasa yoğunlaşmasının bozucu etkileri ayrıştırılmaya çalışılmıştır. Türkiye İstatistik Kurumu'nun 2003-2008 dönemini kapsayan Türkiye imalat sanayi "yerel birim sayısı" ve "istihdam" verileri kullanılarak Bölgesel Uzmanlaşma Endeksi hesaplanmıştır. Sonuçta; bölgeler itibariyle en yüksek uzmanlaşma düzeyine sahip sektörlerde piyasa yoğunlaşması olduğu görülmüştür.

Bayraktutan, Tüylüoğlu, Özbilgin (2012) çalışmasında; önce yığınlaşma analizi ile lojistik sektörünün istatistiki bölgeler düzeyinde yoğunluğu incelenmiş; sonra lojistik geliş̧mişlik endeksiyle her bir il için gelişmişlik endeksi olarak tanımlanabilecek sayısal değerler elde edilerek illerin sıralaması yapılmıştır. Analiz sonuçları Kocaeli’nin Türkiye'nin diğer illerine göre önemli ölçüde lojistik üstünlüklerinin olduğunu ve sektör açısından yüksek bir potansiyel taşıdığını göstermiştir.

Erkan (2012) çalışmasında; 1993-2010 dönemi için Türkiye'nin geleneksel ihraç tarım ürünlerindeki uzmanlaşma düzeyinin belirlenmesini amacıyla 7 ürünün (kuru incir, kuru üzüm, kuru kayısı, fındık, antep fıstığı, ceviz, badem) ihracatına ilişkin uzmanlaşma ve rekabet gücü endeksleri hesaplanmıştır. Bu bağlamda, ihracat payı, ihracat-ithalat oranı endeksi, net ticaret endeksi, Volırath'ın nispi ihracat avantajı endeksi ve Balassa'nın açıklanmış karşılaştırmalı üstünlük endeksi ele alınmıştır. Adı geçen endeks sonuçlarına göre, geleneksel ihraç tarım ürünlerinin 5'inde (incir, kuru üzüm, fındık, antep fıstığı, kuru kayısı) 
uzmanlaşma ve rekabet avantajı mevcut olup 2'sinde de (badem, ceviz) uzmanlaşma yoktur ve rekabet dezavantajı söz konusudur.

Kaynak ve Ari (2012) çalışmasında; N-Firma Yoğunlaşma Oranları $\left(C_{4}\right.$ ve $\left.C_{8}\right)$ ve Herfındahl-Hirschman Endeksi yardımıyla Türk otomotiv sektöründeki yoğunlaşma düzeyi analiz edilmiştir. Yapılan analiz sonucunda $\mathrm{CR}_{4}$ 'e göre yerli binek ve yerli hafif ticari, $\mathrm{CR}_{8}$ 'e göre ise yerli hafif ticari ve ithal hafif ticari araç sektöründe yüksek düzeyde yoğunlaşmanın olduğu görülmüştür. Herfındahl-Hirschman Endeksi analizi sonucunda da yerli hafif ticari ve yerli binek araç sektöründe monopolcü rekabet piyasa yapısı söz konusu iken ithal binek ve ithal hafifi ticari araç sektöründe düşük yoğunlaşma oranı olduğu ve bunun neticesinde daha rekabetçi bir yapının geçerli olduğu görülmüştür.

Manavgat ve Saygııı (2014) çalışmasında; Ege Bölgesi'ndeki endüstriyel faaliyetlerin coğrafi ve sektörel yoğunlaşması, üç Düzey 2 bölgesi için (TR31,TR32,TR33) analiz edilmiştir. Yoğunlaşmanın söz konusu olduğu sektörlerin belirlenmesinde, TÜik 2001 "Yıllık İmalat Sanayi İstatistikleri" ve TÜik 2009 "Yıllık Sanayi ve Hizmet İstatistikleri" verileri kullanılarak Yoğunlaşma Katsayısı analizi yapılmıştır. Çalışmada sektörel yoğunlaşmanın belirlenmesinin yanı sıra yoğunlaşma dinamiğini etkileyen faktörler, Ege Bölgesi'nin Düzey 2' de yer alan alt bölgeleri kapsamında karşılaştırmalı olarak incelenmiştir.

Seçilmiş (2014) çalışmasında; Türkiye'de Kültürel ve Yaratıcı Endüstrilerin (KYE) örgütlenmesi incelenmiştir. Bu kapsamda firma ve işgücü bazında yoğunlaşma katsayıları hesaplanmıştır. Çalışmada Birleşik Krallık Kültür, Medya ve Spor Dairesi (DMCS) sınıflandırması 2013 sürümü esas alınmıştır. Bu sınıflandırmadaki yaratıcı sektörler; Yayımcılık, Yazılım ve Programlama, Tasarım ve Moda Tasarımı, Mimarlık, Reklamcılık ve Pazarlama, Fotoğrafçılık ve Diğer Faaliyetler, Sinema Filmi ve Video, Eğlence ve Sanat, Radyo ve Televizyon, Müzik ve Kültürel Eğitimden oluşmaktadır. Çalışmada kullanılan veri seti, TÜik Kültür İstatistikleri, TÜik Yıllık Sanayi ve Hizmet İstatistikleri, Gelir İdaresi Başkanlığı verileri, Sosyal Güvenlik Kurumu İstatistik Yıllıklarıdır. Çalışmanın ilk etabında yaratıcı kümelerin tespiti için ilgili endüstrilerde faaliyet gösteren firmalara odaklanılmış ve Türkiye'nin illeri için Yoğunlaşma Katsayıları hesaplanmıştır. Çalışmada yapılan analizler değerlendirildiğinde Türkiye'de KYE'de uzmanlaşan 11 il tespit edilmiş fakat Türkiye'de KYE'nin göreli olarak gelişmediği ifade edilmiştir.

Sungur (2015) çalışmasında; Antalya, Isparta ve Burdur illerinde ve bir bütün olarak iBBS Düzey2 TR61 bölgesinde öne çıkan sektörler yoğunlaşma katsayısı yöntemi ile analiz edilmiştir. İl bazında yoğunlaşma katsayılarının hesaplanmasında TÜik 2002 Genel Sanayi ve İşyeri Sayımı verileri, bölge bazında yoğunlaşma katsayılarının hesaplanmasında ise Tüik 2009-2012 Yıllık İmalat Sanayi İstatistikleri kullanılmıştır. Çalışma kapsamında, bölgede yoğunlaşma dinamiğinin belirlenmesi ve bölgesel düzeyde öne çıkan sektörlerin değişiminin ortaya konulması amacıyla 2009-2012 yılları için bölgesel düzeyde sektörel yoğunlaşma katsayıları hesaplanmış ve bölgede zaman içerisinde yoğunlaşma katsayısı artan veya azalan sektörler tespit edilmiştir.

Çamlıca, Akar, Şenkayas (2016) çalışmasında; iBBS Düzey2 TR32 Bölgesi için yapılan yoğunlaşma analizi sonuçları Bölgede karayolu taşımacılığı ile suyolu taşımacılığı sektörlerinin Türkiye’ye oranla daha rekabetçi olduğunu göstermiştir. Muğla ve Aydın illerinin suyolu taşımacılığı bakımından potansiyelinin alt yapı ve genişletilmiş ulaşım güzergâhları ile geliştirilmesinin bölgeyi suyolu taşımacılığında Türkiye'de önemli bir konuma getirebileceği ileri sürülmüştür.

Erkan ve Sunay (2016) çalışmasında; 2000-2014 dönemi için Türkiye'nin ihracatındaki ürün ve pazar çeşitlendirmesi düzeyi Gini-Hirschman Endeksi ve Ticaret Yoğunlaşma Oranı kullanılarak belirlenmiştir. Elde edilen sonuçlar, Türkiye'nin ihracatında pazar ve ürün çeşitlendirmesini gerçekleştirdiğini göstermektedir. İhracatta daha çeşitli ürünle daha fazla ülkeye yayılarak belli ürünlere ve pazarlara olan bağımlılığın azaltılmasını, Türkiye ekonomisi ve rekabet gücü bağlamında olumlu bir gelişme olarak değerlendirmişlerdir.

İskenderoğlu (2017) çalışmasında; Niğde ili için 2006 - 2014 dönemi esas alınarak yıllık frekanstaki bölgesel ve ulusal bir dizi veri dâhilinde Yoğunlaşma Katsayısı analizi gerçekleştirilmiştir. Yoğunlaşma Katsayısı analizinden elde edilen sonuçlar, Niğde ilinin ülke ekonomisine kıyasla hangi yönlerden daha yoğun faaliyette olduğunu ortaya koyarak bölgesel kalkınma sürecinin hangi eksende ilerlediğini göstermiştir. Buna göre madencilik ve taş ocakçılığı ihracatı, tarım ve ormancılık ithalatı, tarım intisas kredileri, toptan ve perakende ticaret ihracatı, mesleki ihtisas kredileri, tarım ve ormancılık ihracatı, bitkisel üretim değeri, resmi kuruluşlar mevduatı, canlı hayvanlar değeri, imalat ihracatı, tasarruf mevduatı alanlarında Niğde ili Türkiye ekonomisine kıyasla daha yoğun faaliyet göstermektedir.

Yıldız (2018) çalışmasında; Borsa İstanbul'da işlem gören finansal olmayan firmaların ihracat yoğunluğu ile performansları arasındaki ilişki incelenmiştir. Buna ilaveten, Ar-Ge yatırımlarının ihracat yoğunluğu ve firma performansı arasındaki ilişki üzerindeki rolü de değerlendirilmiştir. 2005-2015 yılları arasında Borsa İstanbul'da işlem gören 192 şirket ve 2020 gözleme dayanan çalışma sonuçları, ihracat yoğunluğu ile firma performansı arasında pozitif bir ilişki olduğunu, ancak bu pozitif ilişkinin Ar- Ge yatırımı yapan şirketler için geçerli olduğunu göstermiştir. Ar-Ge yatırımı yapmayan işletmelerde ihracat yoğunluğu ile firma performansı arasında herhangi bir ilişki bulunmamıştır. Makalede ayrıca, ihracat yoğunluğu ile firma performansı arasındaki ilişkinin yapısı da incelenmiştir. 


\section{VERI VE YÖNTEM}

Daha çok bölgesel iktisat çalışmalarında yaygınlıkla kullanılan Yoğunlaşma Analizi ile bölgelerin sektör düzeyinde mukayeseli üstünlükleri ortaya konulabilmektedir (Bayraktutan vd., 2012; Çamlıca vd., 2016; İskenderoğlu,2017; Sungur, 2015)

Yoğunlaşma Oranı veya Katsayısı, kolay hesaplanması özelliği nedeni ile bu analizde yaygın olarak kullanılan yoğunlaşma ölçüleridir. Dış ticarette yoğunlaşma oranı esas olarak, belli sayıdaki firma, ürün, sektör veya ülkenin toplam paylarını ifade eden bir kavramdır. Yoğunlaşma oranı "0 ile 100" arasında bir değer almakta ve aşağıda belirtilen formül yardımıyla hesaplanmaktadır. Formülde, $\mathbf{C R}_{\mathbf{m}}$ yoğunlaşma oranını, $\mathbf{P}_{\mathbf{i}}$ ise firma, ürün, sektör veya ülkenin payını göstermektedir (Erkan vd., 2016: 1831; Kaynak vd., 2011:47).

$$
\mathbf{C R}_{\mathrm{m}}=\sum_{\mathrm{i}=1}^{\mathrm{m}} \mathbf{P}_{\mathrm{i}} * 100
$$

İhracat (veya ithalat) yoğunlaşma katsayısı ise il sektör ihracatının (veya ithalatının) il toplam ihracatındaki (veya ithalatındaki) payının, sektörün ülke toplam ihracatındaki (veya ithalatındaki) payına oranlanması ile hesaplanmaktadır ve sektörün ülke ihracatındaki (veya ithalatındaki) göreli üstünlüğünü ifade etmektedir. İ ihracat (ithalat) yoğunlaşma katsayısı (PECR) ise aşağıda gösterilen formül yardımıyla hesaplanmaktadır (GEKA, 2018: 85-86).

$$
\operatorname{PECR}=\left(\mathbf{X}_{\mathrm{IJ}} / \mathbf{X}_{\mathrm{I}}\right) /\left(\mathbf{X}_{\mathrm{J}} / \mathbf{X}\right)
$$

$$
\begin{array}{ll}
\mathbf{X}_{\mathrm{IJ}} \text { : i ilinde j sektörünün ihracatı (ithalatı) } & \mathbf{X}_{\mathbf{J}} \text { : Türkiye'deki j sektörünün toplam ihracatı (ithalatı) } \\
\mathbf{X}_{\mathrm{I}} \text { : i ilinin toplam ihracatı (ithalatı) } & \mathbf{X} \text { : Türkiye'nin toplam ihracatı (ithalatı) }
\end{array}
$$

Katsayının 1'den büyük olması durumunda sektörün öne çıktığı ve uzmanlaşmanın söz konusu olduğu ifade edilir. Yoğunlaşma Oranı ve Katsayısı genellikle istihdam verileri kullanılarak hesaplansa da üretim, katma değer, ihracat (veya ithalat) verileri kullanılarak da hesaplanabilmektedir (Sungur, O., 2015: 323). Analizde 2012-2016 dönemi için Türkiye İstatistik Kurumu Yıllık Dış Ticaret İstatistikleri kullanılmıştır.

\section{BULGU VE TARTIŞMALAR}

\subsection{Genel Dış Ticaret Görünümü}

2016 yılında Denizli'de 737 milyon USD dış ticaret fazlası verilmiştir; 2,4 milyar USD ihracat, 1,6 milyar USD ithalat yapılmıştır. Aynı yıl Aydın, Denizli ve Muğla'dan oluşan Güney Ege Bölgesi'nde 1,3 milyar USD dış ticaret fazlası sağlanmıştır; 3,4 milyar USD ihracat ve 2,1 milyar USD ithalat yapılmıştır. Türkiye genelinde ise 56 milyar USD dış ticaret açı̆̆ı verilmiştir; toplam 142 milyar USD ihracat, 198 milyar USD ithalat yapılmıştır.

Tablo 1: Dış Ticaretin Gelişimi (Milyon USD)

\begin{tabular}{|c|r|r|r|r|r|r|r|r|r|}
\hline \multirow{2}{*}{ Yıllar } & \multicolumn{3}{|c|}{ Denizli } & \multicolumn{3}{c|}{ TR32 } & \multicolumn{3}{c|}{ Türkiye } \\
\cline { 2 - 11 } & ihracat & \multicolumn{1}{|c|}{ ithalat } & Denge & ihracat & ithalat & Denge & ihracat & ithalat & Denge \\
\hline 2012 & 2.623 & 2.262 & 360 & 3.577 & 2.676 & 900 & 152.461 & 236.545 & -84.083 \\
\hline 2013 & 2.741 & 2.208 & 533 & 3.724 & 2.606 & 1.118 & 151.802 & 251.661 & -99.858 \\
\hline 2014 & 2.815 & 2.177 & 639 & 3.902 & 2.549 & 1.353 & 157.610 & 242.177 & -84.566 \\
\hline 2015 & 2.516 & 1.902 & 614 & 3.535 & 2.315 & 1.219 & 143.838 & 207.234 & -63.395 \\
\hline 2016 & 2.403 & 1.666 & 737 & 3.436 & 2.130 & 1.305 & 142.529 & 198.618 & -56.088 \\
\hline Yıllık Ort. Artış (\%) & $-1,97$ & $-7,21$ & 20,99 & $-1,00$ & $-5,54$ & 9,72 & $-1,67$ & $-4,27$ & $-9,63$ \\
\hline
\end{tabular}

Kaynak: TÜiK, Dış Ticaret İstatistikleri

Türkiye toplam dış ticaretinin aksine hem Denizli hem de Güney Ege Bölgesi dış ticaret fazlası vererek ülke ekonomisine katkı sağlamaktadır. 2012 - 2016 döneminde Denizli'de ihracattaki yıllık ortalama \%1,97 azalışa karşın ithalatta \%7,2 düşüş gerçekleşmesi dış ticaret fazlasının artmasına yol açmıştır. Benzer şekilde Güney Ege Bölgesi'nde de dış ticaret fazlası artış 
göstermiştir; ihracattaki ortalama \%1 düzeyindeki azalışa karşın ithalatta \%5,5 düşüş meydana gelmiştir. Türkiye genelinde ise son yıllarda ithalatta meydana gelen düşüş ihracatta meydana gelen düşüşten daha fazla olduğu için dış ticaret açığı azalmıştır; ihracattaki ortalama \%1,6 oranındaki düşüşe karşın ithalat \%4,2 oranında azalmıştır.

Denizli ihracatı ana sektörler itibariyle incelendiğinde, il ihracatında başı çeken ana sektörün imalât sanayii olduğu görülmektedir. İmalât sanayi ihracatı son üç senede \%15 oranında gerileme gösterse de, ilin toplam ihracatının yaklaşık \%96'sını oluşturmaktadır. İlde 2016 yılı itibariyle dış ticaret fazlasının \%97'si imalât sanayiinden kaynaklanmaktadır.

Denizli ithalatı ana sektörler itibariyle incelendiğinde, ihracatta olduğu gibi ithalatta da başı çeken sektör imalât sanayiidir. İmalât sanayii ithalatı, il toplam ithalatının yaklaşık \%95'ini kapsamaktadır. Yıllar itibariyle il inracat ve ithalatının ana sektörlere göre dağııımı aşağıdaki tabloda verilmiştir.

Tablo 2: Denizli ili ỉhracat ve İthalatının Ana Sektörlere Göre Dağılımı (Milyon USD)

\begin{tabular}{|c|c|c|c|c|c|c|c|c|c|}
\hline \multirow{2}{*}{ ISIC Adı } & \multicolumn{3}{|c|}{ İhracat } & \multicolumn{3}{|c|}{ İthalat } & \multicolumn{3}{|c|}{ Dış Ticaret Dengesi } \\
\hline & 2014 & 2015 & 2016 & 2014 & 2015 & 2016 & 2014 & 2015 & 2016 \\
\hline Tarım, Ormancılık ve Balıkçılık & 44 & 44 & 47 & 106 & 115 & 72 & -67 & -76 & -25 \\
\hline Madencilik ve Taşocakçılığı & 60 & 46 & 57 & 0 & 17 & 7 & 60 & 29 & 50 \\
\hline İmalât Sanayi & 2.711 & 2.426 & 2.299 & 2.061 & 1.770 & 1.587 & 650 & 656 & 712 \\
\hline Toplam & 2.815 & 2.516 & 2.403 & 2.167 & 1.902 & 1.666 & 648 & 614 & 737 \\
\hline \multicolumn{10}{|c|}{ Yüzde Dağılım (\%) } \\
\hline Tarım, Ormancılık ve Balıkçılık & 1,56 & 1,75 & 1,96 & 4,89 & 6,05 & 4,32 & $-9,57$ & $-11,56$ & $-3,39$ \\
\hline Madencilik ve Taşocakçılığı & 2,13 & 1,83 & 2,37 & 0,01 & 0,89 & 0,42 & 9,22 & 4,72 & 6,78 \\
\hline İmalât Sanayi & 96,31 & 96,42 & 95,67 & 95,10 & 93,06 & 95,26 & 100,35 & 106,84 & 96,61 \\
\hline Toplam & 100 & 100 & 100 & 100 & 100 & 100 & 100 & 100 & 100 \\
\hline
\end{tabular}

Kaynak: TÜiK, Dış Ticaret İstatistikleri

Güney Ege Bölgesi ihracatı ana sektörler itibariyle incelendiğinde, bölge ihracatında başı çeken ana sektörün Denizli'de olduğu gibi imalât sanayii olduğu görülmektedir. İmalât sanayi ihracatı bölge toplam ihracatının yaklaşık \%85'ini oluşturmaktadır. Bölgede 2016 yılı itibariyle dış ticaret fazlasının \%65'i imalât sanayiinden kaynaklanmaktadır.

Güney Ege Bölgesi ithalatı ana sektörler itibariyle incelendiğinde, ihracatta olduğu gibi ithalatta da başı çeken sektör imalât sanayiidir. İmalât sanayii ithalatı, bölge toplam ithalatının yaklaşık \%95'ini kapsamaktadır. Yıllar itibariyle Güney Ege Bölgesi'nde ihracat ve ithalatın ana sektörlere göre dağılımı aşağıdaki tabloda verilmiştir.

Tablo 3: TR32 Bölgesi Ihracat ve İthalatının Ana Sektörlere Göre Dağılımı (Milyon USD)

\begin{tabular}{|c|c|c|c|c|c|c|c|c|c|}
\hline \multirow{2}{*}{ ISIC AdI } & \multicolumn{3}{|c|}{ İhracat } & \multicolumn{3}{|c|}{ İthalat } & \multicolumn{3}{|c|}{ Dış Ticaret Dengesi } \\
\hline & 2014 & 2015 & 2016 & 2014 & 2015 & 2016 & 2014 & 2015 & 2016 \\
\hline Tarım, Ormancılık ve Balıkçılık & 320 & 326 & 364 & 118 & 131 & 90 & 202 & 195 & 274 \\
\hline Madencilik ve Taşocakçılığı & 198 & 181 & 198 & 8 & 27 & 17 & 190 & 154 & 181 \\
\hline İmalât Sanayi & 3.385 & 3.028 & 2.874 & 2.414 & 2.158 & 2.024 & 971 & 870 & 850 \\
\hline Toplam & 3.903 & 3.535 & 3.436 & 2.550 & 2.316 & 2.131 & 1.353 & 1.219 & 1.305 \\
\hline \multicolumn{10}{|c|}{ Yüzde Dağılım (\%) } \\
\hline Tarım, Ormancılık ve Balıkçılık & 8,2 & 9,2 & 10,6 & 4,6 & 5,7 & 4,2 & 14,9 & 16 & 21 \\
\hline Madencilik ve Taşocakçılığı & 5,1 & 5,1 & 5,8 & 0,3 & 1,1 & 0,8 & 14 & 12,6 & 13,9 \\
\hline İmalât Sanayi & 86,7 & 85,7 & 83,6 & 94,7 & 93,2 & 95 & 71,7 & 71,4 & 65,1 \\
\hline
\end{tabular}




\begin{tabular}{|l|r|r|r|r|r|r|r|r|r|}
\hline Toplam & 100,0 & 100,0 & 100,0 & 100,0 & 100,0 & 100,0 & 100,0 & 100,0 & 100,0 \\
\hline
\end{tabular}

Kaynak: Tüik, Dış Ticaret İstatistikleri

\subsection{Pazar Yoğunlaşma Oranı ile îl Dış Ticaretinin Analizi}

Denizli, 2016 yılı itibariyle toplam 180 ülkeye ihracat yapmıştır. İhracatın büyük kısmı Avrupa ülkeleri ve ABD’yi kapsamaktadır. Başlıca en çok ihracat yapılan ülkeler, Almanya, İngiltere ve ABD'dir. Ülke yoğunlaşma oranı anlamına gelen CR değerinin ihracat kaleminde yüksek olması, ihracatın az sayıda ülkeye yapıldığı anlamına gelmektedir. ilde en çok ihracatın yapıldığı ilk dört ülkenin payını gösteren $\mathrm{CR}_{4}$ değeri \%37 olarak gerçekleşmiş olup bu oran orta derecede pazar yoğunlaşması olduğunu göstermektedir.

2016 yılı itibariyle Denizli ithalat verileri incelendiğinde, ithalatta en büyük payın Rusya Federasyonu'na ait olduğu görülmektedir. Illin en çok ithalat yaptığı ilk dört ülkenin payını gösteren $\mathrm{CR}_{4}$ değeri, 2016 yılında $\% 50$ olarak gerçekleşmiş olup bu oran yüksek derecede pazar yoğunlaşması olduğunu göstermektedir. Hesaplanan yoğunlaşma oranları Denizli ihracat pazarının birkaç ülkeye bağı olmadığını ve ithalat pazarının, ihracat pazarına göre daha dar olduğunu göstermektedir.

Tablo 4: Denizli ilii İhracat ve İthalatının Ülkelere Göre Dağılımı (2016)

\begin{tabular}{|c|c|c|c|c|c|c|c|c|}
\hline \multirow[b]{2}{*}{$\mathbf{C R}_{\mathbf{i}}$} & \multirow[b]{2}{*}{ Ülke } & \multicolumn{2}{|c|}{ İhracat } & \multirow{2}{*}{$\begin{array}{r}\mathrm{CR}_{\mathbf{i}} \\
\text { Oranı } \\
(\%)\end{array}$} & \multirow[b]{2}{*}{ Ülke } & \multicolumn{2}{|c|}{ İthalat } & \multirow{2}{*}{$\begin{array}{r}\mathrm{CR}_{\mathrm{i}} \\
\text { Oranı } \\
(\%)\end{array}$} \\
\hline & & $\begin{array}{r}\text { Milyon } \\
\text { USD }\end{array}$ & Pay (\%) & & & $\begin{array}{r}\text { Milyon } \\
\text { USD }\end{array}$ & Pay (\%) & \\
\hline $\mathrm{CR}_{1}$ & Almanya & 268 & 11,2 & 11,2 & Rusya Fed. & 285,6 & 17,1 & 17,1 \\
\hline CR2 & İngiltere & 240 & 10,0 & 21,1 & Kazakistan & 275,1 & 16,5 & 33,7 \\
\hline $\mathrm{CR}_{3}$ & $A B D$ & 198,3 & 8,3 & 29,4 & Özbekistan & 145,9 & 8,8 & 42,4 \\
\hline $\mathrm{CR}_{4}$ & İtalya & 174,1 & 7,2 & 36,6 & Çin & 132,4 & 7,9 & 50,4 \\
\hline $\mathrm{CR}_{5}$ & Fransa & 119,5 & 5,0 & 41,6 & Türkmenistan & 83,3 & 5,0 & 55,4 \\
\hline $\mathrm{CR}_{6}$ & İsrail & 104,2 & 4,3 & 45,9 & Ukrayna & 81,9 & 4,9 & 60,3 \\
\hline $\mathrm{CR}_{7}$ & Hollanda & 98,8 & 4,1 & 50,1 & Almanya & 61,7 & 3,7 & 64,0 \\
\hline $\mathrm{CR}_{8}$ & Romanya & 70,2 & 2,9 & 53,0 & $A B D$ & 58,1 & 3,5 & 67,5 \\
\hline $\mathrm{CR}_{9}$ & İspanya & 54,7 & 2,3 & 55,3 & İspanya & 56,7 & 3,4 & 70,9 \\
\hline $\mathrm{CR}_{10}$ & Avusturya & 54,2 & 2,3 & 57,5 & Bulgaristan & 48,0 & 2,9 & 73,7 \\
\hline $\mathrm{CR}_{11}$ & Danimarka & 52,9 & 2,2 & 59,7 & Şili & 43,0 & 2,6 & 76,3 \\
\hline $\mathrm{CR}_{12}$ & Çin & 47,6 & 2,0 & 61,7 & İtalya & 36,0 & 2,2 & 78,5 \\
\hline $\mathrm{CR}_{13}$ & Suudi Arabistan & 47,2 & 2,0 & 63,7 & Hindistan & 32,9 & 2,0 & 80,5 \\
\hline $\mathrm{CR}_{14}$ & Irak & 44,8 & 1,9 & 65,5 & Pakistan & 32,8 & 2,0 & 82,4 \\
\hline $\mathrm{CR}_{15}$ & Mısır & 39,7 & 1,7 & 67,2 & Vietnam & 30,4 & 1,8 & 84,3 \\
\hline & Diğer & 789 & 32,8 & 100,0 & Diğer & 263 & 15,8 & 100,0 \\
\hline & Toplam & 2.403 & 100,0 & & Toplam & 1.666 & 100,0 & \\
\hline
\end{tabular}

Kaynak: TÜiK, Dış Ticaret İstatistikleri

TR32 Bölgesi ihracatının 2016 yılı için ülkelere göre dağılımına bakıldığında, bölge ihracatının büyük bölümünün Avrupa ülkeleri ve ABD'ye yapıldığı görülmektedir. Bölgede 2016 yılında toplam 184 ülkeye ihracat yapılmıştır. Aynı yıl ihracat kaleminde gerçekleşen $\mathbf{C R}_{4}$ değeri \%34 olarak gerçekleşmiş olup bu oran orta derecede pazar yoğunlaşması olduğunu göstermektedir.

Bölgenin 2016 yılı için ithalatına bakıldığında, ithalatın yoğun olarak Rusya, Kazakistan ve Çin'den yapıldığı görülmektedir. ìhracatın aksine ithalatta Avrupa ülkeleri değil doğu ülkeleri önemli bir pazardır. 2016 yılında ithalat kaleminde gerçekleşen $\mathrm{CR}_{4}$ değeri \%45 olarak gerçekleşmiş olup bu oran orta derecede pazar yoğunlaşması olduğunu göstermektedir. Hesaplanan 
yoğunlaşma oranları Güney Ege Bölgesi ihracat pazarının de birkaç ülkeye bağlı olmadığını ve ithalat pazarının, ihracat pazarına göre daha dar olduğunu göstermektedir.

Tablo 5. TR32 Bölgesi İhracat ve İthalatının Ülkelere Göre Dağılımı (2016)

\begin{tabular}{|c|c|c|c|c|c|c|c|c|}
\hline \multirow[b]{2}{*}{$\mathbf{C R}_{\mathrm{i}}$} & \multirow[b]{2}{*}{ Ülke } & \multicolumn{2}{|c|}{ İhracat } & \multirow[b]{2}{*}{$\begin{array}{r}\mathbf{C R}_{\mathbf{i}} \\
\text { Oranı } \\
(\%)\end{array}$} & \multirow[b]{2}{*}{ Ülke } & \multicolumn{2}{|c|}{ İthalat } & \multirow[b]{2}{*}{$\begin{array}{r}\mathrm{CR} \\
\text { Oranı } \\
(\%)\end{array}$} \\
\hline & & $\begin{array}{r}\text { Milyon } \\
\text { USD }\end{array}$ & $\begin{array}{l}\text { Pay } \\
\text { (\%) }\end{array}$ & & & $\begin{array}{r}\text { Milyon } \\
\text { USD }\end{array}$ & $\begin{array}{l}\text { Pay } \\
\text { (\%) }\end{array}$ & \\
\hline $\mathrm{CR}_{1}$ & Almanya & 351 & 10,2 & 10,2 & Rusya & 297 & 13,9 & 13,9 \\
\hline CR2 & Ingiltere & 277 & 8,1 & 18,3 & Kazakistan & 275 & 12,9 & 26,9 \\
\hline $\mathrm{CR}_{3}$ & İtalya & 276 & 8,0 & 26,3 & Çin & 236 & 11,1 & 37,9 \\
\hline $\mathrm{CR}_{4}$ & $A B D$ & 263 & 7,7 & 34,0 & Özbekistan & 148 & 7,0 & 44,9 \\
\hline $\mathrm{CR}_{5}$ & Hollanda & 176 & 5,1 & 39,1 & Almanya & 92 & 4,3 & 49,2 \\
\hline $\mathrm{CR}_{6}$ & Fransa & 150 & 4,4 & 43,5 & Ukrayna & 87 & 4,1 & 53,3 \\
\hline $\mathrm{CR}_{7}$ & İsrail & 143 & 4,2 & 47,6 & Türkmenistan & 83 & 3,9 & 57,2 \\
\hline $\mathrm{CR}_{8}$ & Romanya & 98 & 2,8 & 50,5 & İtalya & 77 & 3,6 & 60,8 \\
\hline $\mathrm{CR}_{9}$ & İspanya & 96 & 2,8 & 53,3 & İspanya & 67 & 3,2 & 64,0 \\
\hline $\mathrm{CR}_{10}$ & Çin & 73 & 2,1 & 55,4 & $A B D$ & 61 & 2,9 & 66,8 \\
\hline $\mathrm{CR}_{11}$ & Irak & 69 & 2,0 & 57,4 & Fas & 56 & 2,6 & 69,4 \\
\hline $\mathrm{CR}_{12}$ & S. Arabistan & 67 & 2,0 & 59,3 & Bulgaristan & 49 & 2,3 & 71,7 \\
\hline $\mathrm{CR}_{13}$ & Danimarka & 67 & 2,0 & 61,3 & Şili & 47 & 2,2 & 73,9 \\
\hline $\mathrm{CR}_{14}$ & Avusturya & 58 & 1,7 & 63,0 & Hindistan & 40 & 1,9 & 75,8 \\
\hline \multirow[t]{3}{*}{$\mathrm{CR}_{15}$} & Polonya & 54 & 1,6 & 64,6 & Vietnam & 36 & 1,7 & 77,5 \\
\hline & Diğer & 1.218 & 35,4 & 100,0 & Diğer & 480 & 22,5 & 100,0 \\
\hline & Toplam & 3.436 & 100,0 & & Toplam & 2.131 & 100,0 & \\
\hline
\end{tabular}

Kaynak: TÜiK, Dış Ticaret İstatistikleri

\subsection{Sektörel Yoğunlaşma Oranı ile il Dış Ticaretinin Analizi}

Alt sektörlere göre dağıııma bakıldığında Denizli ihracatında, Tekstil Ürünleri sektörü ilk sırada yer almaktadır. Sektör ihracatı 2014 yılında 921 milyon USD’nin üstüne çıksa da 2015 yılında 824 milyon USD seviyesine gerilemiş ardından 2016 yılında 915 milyon USD seviyesine çıkmıştır. Ana Metal Sanayi, Giyim Eşyası ve Metal Eşya Sanayi sektörlerinde ihracat sürekli bir azalış trendine girmiştir ve sırasıyla \%34, \%12 ve \%38 düzeylerinde azalış gerçekleşmiştir. Diğer yandan Taşocakçוlığı ve Diğer Madencilik, Tarım ve Hayvancılık ile Gıda Ürünleri ve İçecek sektörlerinde sürekli bir artış trendi oluşmuştur ve sırasıyla \%75, $\% 33$ ve \%13 düzeylerinde artış gerçekleşmiştir.

Tablo 6: Denizli ihracatının Alt Sektörlere Göre Dağılımı (Milyon USD)

\begin{tabular}{|l|r|r|r|r|c|}
\hline ISIC Adı & $\mathbf{2 0 1 2}$ & $\mathbf{2 0 1 3}$ & $\mathbf{2 0 1 4}$ & $\mathbf{2 0 1 5}$ & $\mathbf{2 0 1 6}$ \\
\hline 17 - Tekstil Ürünleri & 866 & 836 & 921 & 824 & 915 \\
\hline 27 - Ana Metal Sanayi & 519 & 566 & 527 & 375 & 342 \\
\hline 18 - Giyim Eşyası & 356 & 388 & 373 & 322 & 312 \\
\hline 31 - B.Y.S. Elektrikli Makina ve Cihazlar & 269 & 300 & 334 & 378 & 247 \\
\hline 28 - Metal Eşya Sanayi & 243 & 234 & 205 & 159 & 150 \\
\hline 26 - Metalik Olm. Diğ. Mineral Ürünler & 142 & 156 & 173 & 162 & 161 \\
\hline 15 - Gıda Ürünleri ve İçecek & 56 & 60 & 69 & 89 & 66 \\
\hline 14 - Taşocakçılığı ve Diğer Madencilik & 33 & 58 & 57 & 46 & 57 \\
\hline
\end{tabular}




\begin{tabular}{|l|r|r|r|r|r|}
\hline $1-$ Tarım ve Hayvancılık & 35 & 42 & 39 & 39 & 47 \\
\hline 29 - B.Y.S. Makine ve Teçhizat & 39 & 27 & 33 & 39 & 35 \\
\hline Diğer Sektörler & 65 & 75 & 84 & 83 & 71 \\
\hline Toplam & 2.623 & 2.741 & 2.815 & 2.516 & 2.403 \\
\hline
\end{tabular}

Kaynak: TÜiK, Dış Ticaret İstatistikleri

2012 ve 2016 yılları için Denizli ihracatında ilk 4 sektörün toplam payını gösteren CR $_{4}$ değerleri sırasıyla \%77 ve \%76 olarak gerçekleşirken, ilk 8 ülkenin toplam payını gösteren $\mathbf{C R}_{\mathbf{8}}$ değerleri sırasıyla $\% 95$ ve $\% 94$ olarak hesaplanmıştır. \%70'in üzerindeki CR değerleri çok yüksek derecede yoğunlaşma olduğunu gösterir ve bu durum bir taraftan o ilin o sektörlerde uzmanlaştığını gösterirken diğer taraftan ilin o sektörlere bağımlı olduğu anlamına gelir.

Tablo 7: Denizli îhracatının Alt Sektörlere Göre Dağılımı (\%)

\begin{tabular}{|c|c|c|c|c|c|c|}
\hline \multirow[b]{2}{*}{$\mathbf{C R}_{\mathbf{i}}$} & \multicolumn{2}{|l|}{2012} & \multirow[b]{2}{*}{$\begin{array}{l}\mathrm{CR}_{\mathrm{i}} \\
(\%)\end{array}$} & \multicolumn{2}{|l|}{2016} & \multirow[b]{2}{*}{$\begin{array}{l}C_{\mathbf{i}_{\mathbf{i}}} \\
(\%)\end{array}$} \\
\hline & ISIC Adı & $\begin{array}{l}\text { Pay } \\
\text { (\%) }\end{array}$ & & ISIC Adı & $\begin{array}{l}\text { Pay } \\
\text { (\%) }\end{array}$ & \\
\hline $\mathbf{C R}_{1}$ & Tekstil Ürünleri & 33,0 & 33,0 & Tekstil Ürünleri & 38,1 & 38,1 \\
\hline $\mathbf{C R}_{\mathbf{2}}$ & Ana Metal Sanayi & 19,8 & 52,8 & Ana Metal Sanayi & 14,2 & 52,3 \\
\hline $\mathbf{C R}_{\mathbf{3}}$ & Giyim Eşyası & 13,6 & 66,4 & Giyim Eşyası & 13,0 & 65,3 \\
\hline $\mathrm{CR}_{4}$ & B.Y.S. Elektrikli Makina ve Cihazlar & 10,3 & 76,6 & B.Y.S. Elektrikli Makina ve Cihazlar & 10,3 & 75,6 \\
\hline $\mathbf{C R}_{5}$ & Metal Eşya Sanayi & 9,2 & 85,9 & Metalik Olm. Diğ. Mineral Ürünler & 6,7 & 82,3 \\
\hline $\mathbf{C R}_{6}$ & Metalik Olm. Diğ. Mineral Ürünler & 5,4 & 91,3 & Metal Eşya Sanayi & 6,2 & 88,5 \\
\hline $\mathbf{C R}_{\mathbf{7}}$ & Gıda Ürünleri ve i̇çecek & 2,1 & 93,4 & Gıda Ürünleri ve íçecek & 2,8 & 91,3 \\
\hline $\mathrm{CR}_{8}$ & B.Y.S. Makine ve Teçhizat & 1,5 & 94,9 & Taşocakçılığı ve Diğer Madencilik & 2,4 & 93,7 \\
\hline $\mathbf{C R}_{\mathbf{9}}$ & Tarım ve Hayvancılık & 1,3 & 96,3 & Tarım ve Hayvancılık & 2,0 & 95,6 \\
\hline $\mathbf{C R}_{10}$ & Taşocakçılığı ve Diğer Madencilik & 1,2 & 97,5 & B.Y.S. Makine ve Teçhizat & 1,5 & 97,1 \\
\hline
\end{tabular}

Kaynak: TÜiK, Dış Ticaret ístatistikleri

Denizli ithalatında, alt sektörlere göre dağılıma bakıldığında Ana Metal Sanayi sektörünün ilk sırada yer aldığı görülmektedir. Sektör ithalatı, il toplam ithalatının 2016 yılında \%61'ini oluşturmaktadır. Pek çok sektörde ithalat tutarının 2016 yılında 2012 yılına göre azaldığı görülmekle beraber B.Y.S. Elektrikli Makine ve Cihazlar ile Ağaç ve Mantar Ürünleri sektörleri ithalat tutarlarında artış meydana geldiği görülmektedir; söz konusu artış sırasıyla \%68 ve \%31 düzeylerindedir. En fazla düşüşün Kok Kömürü, Rafine Edilmiş Petrol Ürünleri ve Nükleer Yakıtlar sektörü ile Gıda Ürünleri ve İçecek sektörü, Kâğıt ve Kâğıt Ürünleri sektörlerinde meydana gelmiş olması dikkat çekicidir; söz konusu azalış sırasıyla \%166, \%122 ve \%99 düzeylerindedir. Kok Kömürü, Rafine Edilmiş Petrol Ürünleri ve Nükleer Yakıtlar sektörü ithalatındaki azalışı Denizli'de doğalgaz kullanımının yaygınlaşmasına bağlamak yanlış olmayacaktır.

Tablo 8: Denizli itthalatının Alt Sektörlere Göre Dağılımı (Milyon USD)

\begin{tabular}{|l|r|r|r|r|r|}
\hline ISIC Adı & $\mathbf{2 0 1 2}$ & $\mathbf{2 0 1 3}$ & $\mathbf{2 0 1 4}$ & $\mathbf{2 0 1 5}$ & $\mathbf{2 0 1 6}$ \\
\hline 27 - Ana Metal Sanayi & 1.484 & 1.508 & 1.348 & 1.084 & 1.012 \\
\hline $17-$ Tekstil Ürünleri & 250 & 250 & 255 & 219 & 211 \\
\hline 24 - Kimyasal Madde ve Ürünler & 137 & 97 & 104 & 111 & 97 \\
\hline 29 - B.Y.S. Makine ve Teçhizat & 107 & 103 & 129 & 70 & 89 \\
\hline 1 - Tarım ve Hayvancılık & 96 & 55 & 106 & 115 & 72 \\
\hline 21 - Kâğı̆ ve Kâğı Ürünleri & 63 & 72 & 58 & 49 & 32 \\
\hline 31 - B.Y.S. Elektrikli Makina ve Cihazlar & 9 & 22 & 54 & 46 & 29 \\
\hline $20-$ Ağaç ve Mantar Ürünleri & 14 & 15 & 22 & 20 & 20 \\
\hline $\begin{array}{l}23 \text {-Kok Kömürü, Rafine Edilmiş Petrol } \\
\text { Ürüleri ve Nükleer Yakıtlar }\end{array}$ & 26 & 11 & 16 & 16 & 10 \\
\hline
\end{tabular}




\begin{tabular}{|c|r|r|r|r|r|}
\hline $15-$ Gıda Ürünleri ve içecek & 9 & 12 & 10 & 41 & 4 \\
\hline Diğer & 67 & 64 & 76 & 131 & 91 \\
\hline Toplam & 2.262 & 2.208 & 2.177 & 1.902 & 1.666 \\
\hline
\end{tabular}

Kaynak: TÜiK, Dış Ticaret İstatistikleri

Denizli ithalatında 2012 ve 2016 yılları için ilk 4 sektörün toplam payını gösteren $\mathbf{C R}_{\mathbf{4}}$ değerleri sırasıyla \%87 ve \%85 olarak gerçekleşirken, ilk 8 ülkenin toplam payını gösteren $\mathbf{C R}_{\mathbf{8}}$ değerleri sırasıyla \%96 ve \%95 olarak hesaplanmıştır. \%70'in üzerindeki CR değerleri çok yüksek derecede yoğunlaşma olduğunu gösterir ve bu durum o sektörlerdeki ürünlerin tedarikinde sıkıntı yaşanması halinde o ilin ekonomisinin zarar görebileceği anlamına gelir.

Tablo 9: Denizli İthalatının Alt Sektörlere Göre Dağılımı (\%)

\begin{tabular}{|c|c|c|c|c|c|c|}
\hline \multirow[b]{2}{*}{$\mathbf{C R}_{\mathbf{i}}$} & \multicolumn{3}{|l|}{2012} & \multicolumn{3}{|l|}{2016} \\
\hline & ISIC Adı & $\begin{array}{l}\text { Pay } \\
(\%)\end{array}$ & $\begin{array}{l}\mathrm{CR}_{\mathrm{i}} \\
(\%) \\
\end{array}$ & ISIC Adı & $\begin{array}{l}\text { Pay } \\
(\%)\end{array}$ & $\begin{array}{l}\mathrm{CR}_{\mathrm{i}} \\
(\%) \\
\end{array}$ \\
\hline $\mathbf{C R}_{1}$ & Ana Metal Sanayi & 65,6 & 65,6 & Ana Metal Sanayi & 60,7 & 60,7 \\
\hline $\mathbf{C R}_{\mathbf{2}}$ & Tekstil Ürünleri & 11,0 & 76,6 & Tekstil Ürünleri & 12,7 & 73,4 \\
\hline $\mathrm{CR}_{3}$ & Kimyasal Madde ve Ürünler & 6,1 & 82,7 & Kimyasal Madde ve Ürünler & 5,8 & 79,2 \\
\hline $\mathrm{CR}_{4}$ & B.Y.S. Makine ve Teçhizat & 4,7 & 87,4 & B.Y.S. Makine ve Teçhizat & 5,4 & 84,6 \\
\hline $\mathrm{CR}_{5}$ & Tarım ve Hayvancılık & 4,2 & 91,7 & Tarım ve Hayvancılık & 4,3 & 88,9 \\
\hline $\mathbf{C R}_{6}$ & Kâğıt ve Kâğıt Ürünleri & 2,8 & 94,5 & Radyo, TV, Haberleşme Cihazları & 2,4 & 91,3 \\
\hline $\mathbf{C R}_{7}$ & $\begin{array}{l}\text { Kok Kömürü, Rafine Edilmiş Petrol } \\
\text { Ürünleri ve Nükleer Yakıtlar }\end{array}$ & 1,1 & 95,6 & Kâğıt ve Kâğıt Ürünleri & 1,9 & 93,2 \\
\hline $\mathrm{CR}_{8}$ & Plastik ve Kauçuk Ürünleri & 0,8 & 96,4 & B.Y.S. Elektrikli Makina ve Cihazlar & 1,7 & 94,9 \\
\hline $\mathbf{C R}_{\mathbf{g}}$ & Metal Eşya Sanayi & 0,7 & 97,1 & Ağaç ve Mantar Ürünleri & 1,2 & 96,1 \\
\hline $\mathrm{CR}_{10}$ & Ağaç ve Mantar Ürünleri & 0,6 & 97,7 & Plastik ve Kauçuk Ürünleri & 0,6 & 96,7 \\
\hline
\end{tabular}

Kaynak: TÜiK, Dış Ticaret İstatistikleri

\subsection{Yoğunlaşma Katsayısı İle İI Dış Ticaretinde Öne Çıkan Sektörler}

Yoğunlaşma analizi yapılırken, 2012-2016 dönemine ait dış ticaret verileri kullanılmış olup, öne çıkan sektörler hesaplanırken katsayının tüm yıllarda 1'in üstünde olması gerekliliği dikkate alınmıştır. Yoğunlaşma katsayılarının tamamı için, 1'in üzerindeki değerler sektörün Denizli'deki göreli üstünlüğünü (avantajını) ifade etmektedir. Buna göre Denizli ihracatına bakıldığında, yoğunlaşma katsayısı en yüksek sektör Tekstil Ürünleri sektörüdür. İlde diğer öne çıkan sektörler aşağıdaki tabloda verilmiştir.

Tablo 10: Denizli ìhracatında Sektörlere Göre Yoğunlaşma Katsayıları

\begin{tabular}{|l|r|r|r|r|r|c|}
\hline Sektör Adı & $\mathbf{2 0 1 2}$ & $\mathbf{2 0 1 3}$ & $\mathbf{2 0 1 4}$ & $\mathbf{2 0 1 5}$ & $\mathbf{2 0 1 6}$ & Ort. \\
\hline Tekstil Ürünleri & 3,80 & 3,14 & 3,35 & 3,47 & 4,01 & 3,55 \\
\hline B.Y.S. Elektrikli Makine ve Cihazlar & 2,67 & 2,57 & 2,94 & 3,98 & 2,80 & 2,99 \\
\hline Metalik Olm. Diğ. Mineral Ürünler & 2,02 & 2,01 & 2,24 & 2,41 & 2,65 & 2,27 \\
\hline Metal Eşya Sanayi & 2,14 & 1,84 & 1,55 & 1,40 & 1,45 & 1,68 \\
\hline Taşocakçı̆ı̆̆ ve Diğer Madencilik & 1,19 & 1,70 & 1,77 & 1,62 & 2,09 & 1,67 \\
\hline Giyim Eşyası & 1,73 & 1,69 & 1,52 & 1,47 & 1,49 & 1,58 \\
\hline Ana Metal Sanayi & 1,04 & 1,79 & 1,77 & 1,21 & 1,14 & 1,39 \\
\hline Balıkçılık & & 0,69 & 0,83 & 0,79 & & 0,77 \\
\hline Maden Kömürü, Linyit ve Turb & & 0,05 & 0,01 & 0,00 & 2,09 & 0,54 \\
\hline Tarım ve Hayvancılık & 0,40 & 0,42 & 0,37 & 0,39 & 0,52 & 0,42 \\
\hline Gıda Ürünleri ve İ̧̧ecek & 0,34 & 0,31 & 0,34 & 0,50 & 0,40 & 0,38 \\
\hline Kâğıt ve Kâğıt Ürünleri & 0,23 & 0,19 & 0,17 & 0,18 & 0,14 & 0,18 \\
\hline
\end{tabular}




\begin{tabular}{|l|l|l|l|l|l|l|}
\hline Tabaklanmış Deri, Bavul, El Çan. ve Ayakkabı & 0,22 & 0,17 & 0,14 & 0,21 & 0,16 & 0,18 \\
\hline Mobilya ve B.Y.S. Diğer Ürünler & 0,20 & 0,18 & 0,15 & 0,18 & 0,16 & 0,18 \\
\hline B.Y.S. Makine ve Teçhizat & 0,19 & 0,12 & 0,14 & 0,18 & 0,18 & 0,16 \\
\hline
\end{tabular}

Kaynak: TÜik, Dış Ticaret İstatistikleri

Denizli ithalatında Ana Metal Sanayi, yoğunlaşma katsayısının en yüksek olduğu sektördür. Tekstil Ürünleri sektörü ise tıpkı ihracatta olduğu gibi ithalatta da yoğunlaşma katsayısının yüksek olduğu bir sektördür; öyle ki ikinci en yüksek yoğunlaşma katsayısına sahiptir. Denizli'de ithalatın yoğunlaştığı diğer sektörler aşağıdaki tabloda verilmiştir.

Tablo 11: Denizli İthalatında Sektörlere Göre Yoğunlaşma Katsayıları

\begin{tabular}{|l|r|r|r|r|r|r|}
\hline Sektör Adı & $\mathbf{2 0 1 2}$ & $\mathbf{2 0 1 3}$ & $\mathbf{2 0 1 4}$ & $\mathbf{2 0 1 5}$ & $\mathbf{2 0 1 6}$ & Ort. \\
\hline Ana Metal Sanayi & 5,85 & 4,89 & 5,67 & 5,38 & 5,41 & 5,44 \\
\hline Tekstil Ürünleri & 4,79 & 4,84 & 4,73 & 4,65 & 5,23 & 4,85 \\
\hline Kâğıt ve Kâğı Ürünleri & 1,90 & 2,20 & 1,66 & 1,55 & 1,09 & 1,68 \\
\hline Ağaç ve Mantar Ürünleri & 1,01 & 1,20 & 1,75 & 1,55 & 2,07 & 1,52 \\
\hline Tarım ve Hayvancılık & 1,38 & 0,03 & 1,39 & 1,78 & 1,24 & 1,16 \\
\hline Metalik Olm. Diğ. Mineral Ürünler & 0,51 & 0,49 & 0,58 & 0,53 & 0,54 & 0,53 \\
\hline B.Y.S. Makine ve Teçhizat & 0,54 & 0,50 & 0,66 & 0,39 & 0,51 & 0,52 \\
\hline Maden Kömürü, Linyit ve Turb & & & & 0,60 & 0,30 & 0,45 \\
\hline B.Y.S. Elektrikli Makine ve Cihazlar & 0,12 & 0,29 & 0,74 & 0,64 & 0,41 & 0,44 \\
\hline Kimyasal Madde ve Ürünler & 0,45 & 0,33 & 0,33 & 0,40 & 0,40 & 0,38 \\
\hline Plastik ve Kauçuk Ürünleri & 0,43 & 0,37 & 0,38 & 0,28 & 0,24 & 0,34 \\
\hline Gıda Ürünleri ve İçecek & 0,18 & 0,25 & 0,20 & 0,87 & 0,10 & 0,32 \\
\hline Atık ve Hurdalar & 0,03 & 0,01 & 0,03 & 1,24 & 0,03 & 0,27 \\
\hline Metal Eşya Sanayi & 0,40 & 0,22 & 0,22 & 0,28 & 0,22 & 0,27 \\
\hline Basım ve Yayım; Plak, Kaset vb. & 0,02 & 0,08 & 0,41 & 0,45 & 0,35 & 0,26 \\
\hline
\end{tabular}

Kaynak: TÜik, Dış Ticaret İstatistikleri

\section{SONUÇ}

Bu çalışmada 2012-2016 dönemi için Denizli, Güney Ege (TR32) Bölgesi ve Türkiye bazında dış ticaret verileri incelenmiştir ve karşılaştırma yöntemi ile il, bölge ve ülke düzeyinde değerlendirmeler yapılmıştır.

Türkiye toplam dış ticaretinin aksine hem Denizli hem de Güney Ege Bölgesi dış ticaret fazlası vererek Türkiye'nin dış ticaret açı̆̆ına olumlu katkı sağlamaktadır. Denizli ve Güney Ege Bölgesi dış ticareti ana sektörler itibariyle incelendiğinde hem ihracatta hem de ithalatta başı çeken sektörün imalât sanayii olduğu görülmektedir.

Hesaplanan yoğunlaşma oranları hem Denizli hem de Güney Ege Bölgesi ihracat pazarının birkaç ülkeye bağlı olmadığını ve ithalat pazarının, ihracat pazarına göre daha dar olduğunu göstermektedir. illde en çok ihracat yapılan ilk dört sektör, toplam il ihracatının \%76'sına karşılık gelmektedir; en çok ithalat yapılan ilk dört sektör, toplam il ithalatının \%85'ine karşılık gelmektedir. $\mathrm{CR}_{4}$ yoğunlaşma düzeyinin $\% 70$ 'ten büyük olması çok yüksek derecede sektörel yoğunlaşma olduğunu göstermektedir.

Yoğunlaşma katsayısı ile il ihracat ve ithalatında öne çıkan ve uzmanlaşmanın söz konusu olduğu sektörler tespit edilmiştir. Buna göre il ihracatında öne çıkan sektörler; Tekstil Ürünleri, B.Y.S. Elektrikli Makine ve Cihazlar, Metalik Olmayan Diğer Mineral Ürünler, Metal Eşya Sanayi, Taşocakçılığı ve Diğer Madencilik, Giyim Eşyası ve Ana Metal Sanayi'dir. İthalatta öne çıkan sektörler; Ana Metal Sanayi, Tekstil Ürünleri, Kâğıt ve Kâğıt Ürünleri, Ağaç ve Mantar Ürünleri, Tarım ve Hayvancılıktır.

Denizli'nin dış ticaretinde sektörel yoğunlaşmanın pazar yoğunlaşmasından daha yüksek olduğu görülmektedir. Sektörel yoğunlaşma eğer yoğunlaşılan sektörlerde gerçek bir uzmanlaşma olmasından ve bu sayede yüksek katma değerli üretim yapılmasından kaynaklanıyorsa olumsuz bir durum olarak değerlendirilmeyebilir. illin üretim ve ihracat stratejisi belli sektörlerde katma değer artışı sağlanması üzerine kurulabileceği gibi üretim ve ihracatta sektör ve ürün çeşitliliğinin artırılması 
üzerine de kurulabilir. Özellikle kaynakların sınırı olduğu durumlarda, kısa vadede, yoğunlaşmanın en yüksek olduğu sektörlere odaklanılması uygulanan stratejilerden daha hızlı sonuç alınmasını sağlayacaktır.

\section{KAYNAKÇA}

Akal, M. (2009). Türkiye-Rusya ve Ukrayna Dış Ticaretinde Fasıl Yoğunlaşması, Karşılaştırmalı Üstünlükler ve Yapısal Değişimler. Akademik Bakıss, 16, 1-15.

Akın, N.(2006). Bölgesel Kalkınma Araçları Ille Kalkınma Ajanslarının Uyum, İşbirliği ve Koordinasyonu. Bölgesel Kalkınma ve Yönetişim Sempozyumu, TEPAV, 295-304.

Arip, M.A., Yee, L.M., Abdul Karim, B. (2010). Export Diversification and Economic Growth in Malaysia. MPRA Paper 20588, 1-10, University Library of Munich, Germany.

Ayrancı, E. (2009). Türkiye'nin Ekonomik Açıdan Küreselleşmesinin Yoğunlaşma Vasıtasıyla Ölçülmesi ve Konu Hakkında Bir Araştırma. Anadolu Bil MYO Dergisi. 4(16): 50-64.

Bayraktutan, Y., Tüylüoğlu Ş., Özbilgin M. (2012). Lojistik Sektöründe Yoğunlaşma Analizi ve Lojistik Gelişmişlik Endeksi: Kocaeli Örneği. Uluslararası Alanya İ̧̧letme Fakültesi Dergisi. 4(3): 61-71.

Çamlıca, Z., Akar, G., Şenkayas, H. (2016). TR32 Bölgesinin Lojistik Açıdan Analizi. Aydın iktisat Fakültesi Dergisi. 1(2): 73-88.

Doğan, S. ve Soyyiğit Kaya, S. (2011). Gümrük Birliği Sonrasında (1996-2009) Türkiye'nin AB ile Dış Ticaretinin Ülke ve Fasıl Bazlı Yoğunlaşma Analizi. Ekonometri ve Istatistik, 14, 1-18.

Erkan, B. (2012). Türkiye'nin Geleneksel İhraç Tarım Ürünlerinde Uzmanlaşma Düzeyi. Sosyal ve Beşeri Bilimler Dergisi. 4(1):75-83.

Erkan, B. \& Sunay, Z. Fatih (2016). Türkiye'nin ihracatının Yoğunlaşma Perspektifinde Analizi. Insan ve Toplum Bilimleri Araştırmaları Dergisi. 5(7):1823-1842.

GEKA (T.C. Güney Ege Kalkınma Ajansı) (2018). Aydın Serbest Bölgesi Fizibilite Etüdü. Yayınlanmamış Rapor, 76-83.

Gündem, F., Acar, S. (2011). Türkiye İmalat Sanayi'nde Bölgesel Uzmanlaşma(2003-2008). Anadolu International Conference in Economics II. Hamid, Z. (2010). Concentration of Exports and Patterns of Trade: A Time Series Evidence. The Journal of Developing Areas. 43(2): 255-270. Hesse, H. (2008). Export Diversification and Economic Growth. The World Bank Commission on Growth and Development, 21, 1-25.

İskenderoğlu, Ö. , Gülseren, M. (2017). Bölgesel Kalkınmada Etkili Faktörlerin Yoğunlaşma Katsayısı Ille İncelenmesi: Niğde İli Örneği. Nevşehir Hacı Bektaş Veli Üniversitesi SBE Dergisi. 7 (2): 18-34.

Kalkınma Bakanlığı (2013). illerin ve Bölgelerin Sosyo-Ekonomik Gelişmişlik Sıralaması Araştırması (SEGE-2011), Bölgesel Gelişme ve Yapısal Uyum Genel Müdürlüğü, Ankara.

Kaya, A. A. (2006). İmalat Sanayi Ihracatında Uzmanlaşma: Türkiye -Avrupa Birliği Analizi (1991-2003). Ege Academic Review, 6, 73-82.

Kaynak, S., Ari, Y. O. (2011). Türk Otomotiv Sektöründe Yoğunlaşma: Binek ve Hafif Ticari Araçlar Üzerine Bir Uygulama. Ekonomik Yaklaşım. 22(80): 39-58.

Lazzeretti, L., Capone, F., Seçilmiş, E. (2014). Türkiye'de Yaratıcı ve Kültürel Sektörlerin Yapısı. Maliye Dergisi, 166, 195-220.

Sungur, O. (2015). TR61 (Antalya, Isparta, Burdur) Bölgesinde Sektörel Yoğunlaşmanın ve Yoğunlaşma Dinamiklerinin Analizi. Yönetim ve Ekonomi Araştırmaları Dergisi. 13(3): 316-341. DOI: 10.11611/JMER695

Wolff, Edward N. (2000). Has Canada Specialized in the Wrong Manufacturing Industries? Centre for the Study of Living Standarts (CSLS) Conference on the Canada-US Manufacturing Productivity Gap, V:85, Ottawa, Ontorio, Canada.

Yıldız, Y. (2018). İhracat Yoğunluğu, Ar-Ge Yatırımları ve Firma Performansı: Türkiye Örneği. Ege Akademik Bakış. 18(2): 307-319.

TÜiK (Türkiye İstatistik Kurumu). Dış Ticaret İstatistikleri. http://tuik.gov.tr/UstMenu.do?metod=kategorist. Erişim: 22.08.2018

TÜiK (Türkiye İstatistik Kurumu). II Göstergeleri. https://biruni.tuik.gov.tr/ilgosterge/?locale=tr. Erişim: 16.11.2018

Türkiye Kalkınma Planları. Erişim: 30.08.2018

http://www3.kalkinma.gov.tr/PortalDesign/PortalControls/WebContentGosterim.aspx?Enc=51C9D1B02086EAFBDCF6B4EA3F896DFD. 